\title{
Posibilismo, memoria y reflexividad. La oposición a la dictadura en el cine del tardofranquismo y la Transición (1969-1977)
}

\author{
JORGE NiETO FERRANDO \\ Universitat de Lleida (Espanya) \\ orcid.org/0000-0003-3075-2636
}

Presentació: 6 set. 2016 | Acceptació: 30 set. 2016 | Publicació: 15 des. 2016

Citació recomanada: NIETO FERRANDo, Jorge. «Posibilismo, memoria y reflexividad. La oposición a la dictadura en el cine del tardofranquismo y la Transición (1969-1977)». Franquisme \& Transició. Revista d'Història i de Cultura 4 (2016): 201-217. doi: http://dx.doi.org/10.7238/fit.voi4.3092

Resumen: El presente artículo aborda algunas de las formas de oposición a la dictadura, así como sus límites, en el cine producido entre 1969 y 1977. En concreto nos detendremos en el cine posibilista y en su crisis ante las exigencias de mayor literalidad por parte del público y la crítica, en las consecuencias de la aparición de unos nuevos límites de lo decible y lo visible, sobre todo en el tratamiento fílmico de la Guerra Civil, y en la lucha en el plano del discurso del cine de no ficción alternativo.

Palabras clave: tardofranquismo, Transición, posibilismo, cine opositor, cine alternativo.

\section{Possibilism, memory and reflexivity: Opposition to dictatorship in cinema produced during the late Francoist era and during the transition to democracy in Spain (1969-1977)}

Abstract. This article addresses some of the forms of opposition to the Franco dictatorship that are to be found in films produced between 1969 and 1977, as well as the obstacles that such films encountered. We will focus in particular on so-called "possibilist" cinema and the crisis that it faced as a result of audiences' and critics' demands for greater literalness; on the consequences of the emergence of new boundaries with regard to what could then be spoken about and visually portrayed, especially in terms of the filmic treatment of the Spanish Civil War; and finally on the arguments found within the discourse of independent non-fiction cinema.

Keywords: Late Francoism, transition, possibilism, film opposition, alternative cinema. 


\section{Introducción}

En el tardofranquismo y el comienzo de la Transición se asiste, en el cine que aborda el presente y el pasado con voluntad crítica dentro de los canales institucionales de producción, distribución y exhibición, a la sustitución de unos márgenes de lo posible — de lo decible y lo visible - por otros, de unas limitaciones a la libertad de expresión impuestas por la dictadura franquista a la asunción tácita del «consenso» con la voluntad de no enturbiar la implantación de la democracia. Este nuevo marco supone la paulatina sustitución del discurso posibilista — del denominado «cine metafórico»— por tratamientos del presente y del pasado más literales, sin elusiones ni subterfugios, pero también evidencia sus limitaciones y genera unas inercias - sobre todo en las películas centradas en la Guerra Civil- que han perdurado hasta la actualidad. Al mismo tiempo, ya a finales de los años sesenta surge un cine independiente de no ficción con planteamientos mucho más radicales, tanto en sus contenidos como en su discurso, cuyo objetivo es contrainformar e incluso en algunos casos despertar la acción política. El hecho de moverse en los márgenes externos de las instituciones le confiere gran libertad, pero también supone importantes dificultades para acceder a un público amplio. Este cine alternativo entra en crisis a partir de 1977, con la supresión de la censura. El objetivo de este artículo es abordar algunas de las formas de oposición a la dictadura, así como sus límites, en el cine producido entre 1969 y 1977. En concreto nos detendremos en el cine posibilista y en su crisis ante las exigencias de mayor literalidad por parte del público y la crítica, en las consecuencias de la aparición de unos nuevos límites de lo decible y lo visible, sobre todo en el tratamiento fílmico de la Guerra Civil, y en la lucha en el plano del discurso del cine de no ficción alternativo.

\section{Perpetuación y crisis del posibilismo}

Al final del franquismo se da lo que analistas, críticos e historiadores denominan «cine metafórico». En sentido estricto, más que a la metáfora que también - este cine recurre a la ironía, al símbolo, a la alegoría, al sí- 
mil, a la parodia, a la alusión, a algunos efectos basados en la ordenación de elementos narrativos, a la metonimia, a la sinécdoque, a las elipsis narrativas que esconden referencias inaceptables, etc. Todos estos recursos pueden desplegarse como una actitud previa para intentar eludir las limitaciones impuestas a la libertad de expresión, aunque en ocasiones llega más lejos que la censura realmente existente, o como una reacción ante las propias «sugerencias» de los censores, intentando decir y mostrar lo mismo que lo proscrito de una manera más críptica o suavizada. De hecho, nada de esto pasa desapercibido para la institución censora, que permite ciertas películas por resultar más costoso en términos de imagen -internacional, dado que algunas superan las fronteras españolas y sus directores tienen cierto prestigio en el extranjero - prohibirlas. Y las consecuencias a nivel interno son mínimas, dado que la mayor parte de los espectadores no acuden a las salas de cine a verlas, y, si van, efectúan «lecturas literales» en las que pasan desapercibidas las alusiones críticas a la dictadura. Según la lógica de la censura, sus efectos también son muy limitados entre el público capacitado para ir más allá de las lecturas evidentes, pues «ya está convencido».

La actitud de la censura ante el cine metafórico puede apreciarse muy bien en uno de los informes de Ana y los lobos (1973), dirigida por Carlos Saura y producida por Elías Querejeta, que recoge Neuschäfer:

Una película de Saura y Querejeta tiene que ser, casi necesariamente, una película de crítica política y social, orientada desde su peculiar punto de vista. Como las circunstancias no les permiten hacer una crítica directa la hacen a través de símbolos. Y eso es esta película: puros símbolo de la España que ellos ven y de sus tradicionales y «vigentes defectos». [...] Si se prohíbe o mutila, el escándalo fuera y dentro de España. Si se autoriza, los varios inconvenientes que de ello se derivan. Ahora bien: creo que sopesando unos y otros riesgos, pesa más el de la prohibición, pues en cierto modo es hacer el juego al sector que representan los autores. La exhibición de la película en España no conmoverá las convicciones de nadie que no esté ya convencido. Y al final pasará sin dejar huella política. [...] En el extranjero, aunque algunos sectores airea- 
rán la intención de Saura, no tendrá la resonancia que la prohibición, pues quedarán como desarmadas por el mismo hecho de la autorización. ${ }^{1}$

En primer lugar, la «tolerancia» de la censura entronca con lo que podríamos denominar «posibilismo institucional». Este se desarrolla sobre todo en la década de los sesenta, durante la etapa de José María García Escudero en la Dirección General de Cinematografía y Teatro (1962-1968), y conduce al estímulo y la promoción de ciertas películas desde la Administración entonadas con el cine moderno europeo que podían abordar temas de difícil digestión para las instituciones franquistas — piénsese, por ejemplo, en La caza (Carlos Saura, 1966) o en Nueve cartas a Berta (Basilio Martín Patino, 1966)—, pero con algún recorrido internacional, lo que permitía mostrar en el exterior cierto grado de aperturismo.

En segundo lugar, e inevitablemente ligado a lo anterior, el uso de una serie de estrategias retóricas para enmascarar ciertos mensajes conflictivos nos conduce a lo que podemos denominar "posibilismo discursivo", una suerte de negociación con la censura que permite superar los límites de lo visible y lo decible. Es necesario señalar que aquí la función de la retórica es la elusión, aunque no reniegue del todo de su clásica utilidad persuasiva, y que este discurso requirió de la particular colaboración de un espectador capacitado para dilucidar los significados ocultos tras los aparentes. A ello contribuyeron sin duda las sesiones cineclubistas y la crítica cinematográfica, dado que muchas veces aportaron algunas claves para la lectura entre líneas de las películas. En ocasiones el espectador llegó en su interpretación más lejos que la intencionalidad del texto fílmico, lo que potenció la carga opositora de ciertos títulos por el mero hecho de la existencia de censura, pues esta le invitaría a sospechar de la posibilidad de utilizar ciertas estrategias elusivas.

En el periodo que analizamos es el director Carlos Saura y el productor Elías Querejeta quienes llegan a exprimir al máximo los recursos posibilistas con las películas El jardín de las delicias (1970), Ana y los lobos (1973) y La prima Angélica (1974). Las tres destripan la familia como cé-

1 Hans-Jörg Neuschäfer, Adiós a la España eterna. La dialéctica de la censura. Novela, teatro y cine bajo el franquismo (Barcelona: Anthropos, 1994), 323-324. 
lula social elemental, origen e imagen de estructuras mayores, en la que fluyen concentradas la represión sexual y una religión macabra, autopunitiva y ritualizada hasta el extremo. Recurren, de hecho, a lo que Neuschäfer, siguiendo a Freud, denomina «condensación»: «La concentración y reducción de un contexto amplio a un pequeño denominador», ${ }^{2}$ que en este caso es la familia, detrás de la que planea la dictadura franquista, invocada de manera implícita.

El jardín de las delicias combina la referencia al presente tardofranquista y sus escándalos económicos con la presencia del recuerdo de la Guerra Civil. La primera escena ya contiene la voluntad explícita de mostrar de manera visual la cochambre y el óxido que corroe el progreso y el desarrollo oficialmente coreado. La historia se centra en la recuperación de la memoria de Antonio - cabeza de familia de uno de los clanes adinerados vencedores de la guerra - tras un accidente y, con ella, de los codiciados números de sus cuentas en Suiza. Con este objetivo su familia recurre a la reconstrucción de determinadas escenas de la vida del protagonista, que emparentan su biografía personal con la historia de España. Así, por ejemplo, su primera comunión, el 14 de abril de 1931, coincide con la llegada de la República. La representación de la entrada de los republicanos al ritmo del himno de Riego en la iglesia donde se celebra produce su levantamiento de la silla de ruedas en la que permanece postrado Antonio, una mejora sustancial de su salud. Otras escenas le hacen revivir algunos aspectos de su carácter, como la sed de sangre cuando sus amigos atan un pichón para que ejercite su antigua afición a la caza, o los rasgos despóticos que desarrolló desde que accede a la dirección de la empresa familiar tras reconocerse en un discurso paternalista sobre las fluidas relaciones entre trabajadores y empresarios. Aquí, varias fotografías evocadoras describen la evolución del negocio desde la pequeña factoría que su abuelo regentó, en el fondo de La carga (1899) — el cuadro de Ramón Casas en el que un guardia civil a caballo avasalla a varios manifestantes-, hasta la constructora que aprovechó la posguerra para enriquecerse con contratas de viviendas y pantanos. 
Ana y los lobos desarrolla en mayor medida las alusiones a la realidad contextual de El jardín de las delicias, y llega, mediante la sinécdoque, a componer una nítida alegoría fácilmente identificable. La película narra el quebranto del remanso de paz y silencio de la casa aislada (España) que supone la irrupción de un elemento extraño y moderno. Ana es una institutriz inglesa contratada para educar a los niños de la familia. Su llegada perturba el ambiente cerrado, y estallan las perversiones candentes de los tres hermanos, que acaban por devorarla tras rondarla sin éxito: lo nuevo es suprimido para que todo permanezca igual. El orden se asienta sobre la represión militar, sexual y religiosa, encarnada en los tres hermanos -José colecciona uniformes militares, Juan es un obseso sexual, y Fernando, un místico autopunitivo-, y sobre la casa, encabezada por una madre - patria - todopoderosa, preocupada solo por su unidad a toda costa.

Finalmente, La prima Angélica vuelve a apuntar de manera más certera hacia la memoria de la Guerra Civil y las divisiones que provocó. La familia aquí está partida por el conflicto. La exhumación y el traslado de los restos de la madre de Luis a la ciudad provinciana en la que viven algunos de sus allegados le conducen a un viaje al verano de 1936, en el que un mes con sus tías y su abuela se convirtió en tres años de sufrir la ausencia sus padres, que vivían en Madrid. Luis es el vástago podrido, el hijo de un republicano que llevó por el mal camino a su madre. En sus recuerdos afloran contrastados el cariño de las tías y los padecimientos y vejaciones que sufrió de su tío por llevar en la sangre la marca del enemigo; también la contraposición entre la educación libre que recibió en Madrid y la escuela religiosa y el tiempo ritualizado de la provincia. La memoria le lleva a recuperar el asombro ante un tiempo extraño e incomprensible desde la óptica de la infancia. De manera similar a El jardín de las delicias, el recuerdo viene confundido con el presente, en este caso sin marcas visuales que lo identifiquen con claridad, motivado por lo más insignificante y generando un efecto bucle, en el que nada cambia o todo se repite a pesar del tiempo trascurrido entre 1936 y los últimos años del franquismo.

La crítica contribuyó a dilucidar el discurso posibilista de estas películas. En su comentario a La prima Angélica, por ejemplo, y acudiendo a su 
mismo lenguaje elusivo, Iván Tubau partía de la película para plantear la necesidad de lecturas entre líneas como una constante del cine y la literatura más inquietos:

Las cosas que cuenta La prima Angélica pertenecen a un código que para un extranjero poco informado de la historia reciente de España pueden parecer casi de ciencia-ficción, en tanto que a muchos españoles nos resultan dolorosamente próximas. [...] Imaginen uno de los temas clásicos del género: la nave que traslada a otra galaxia a, digamos, doscientos «emigrantes». El viaje va a durar cuarenta años [...]. Cuando la nave finalice su largo viaje y vean el mundo de verdad [...], su vida anterior en el mundo artificial de la nave les parecerá un mal sueño lusitano: habrá sido un paréntesis sin poder comprobar que antes y después de él estaba el verdadero discurso. Dentro del paréntesis, no obstante, hay que vivir, único modo de poder salir un día de él. Hay que hacer cosas, escribir Tiempo de silencio si el pasajero se llama Luis Martín Santos, rodar La prima Angélica si se llama Carlos Saura. Para expresarse, los hombres encargados en el paréntesis habrán de inventar un nuevo código lingüístico, pues las posibilidades de expresión en la nave (por disposición de sus tripulantes) no pueden ser las mismas que en el mundo exterior: habrán de ingeniárselas para hablar de lo que pasa en la nave, diciendo bajo signos más o menos cabalísticos lo que no se puede decir de otra manera. Con ello [...] dirán lo que puedan, que ya es mérito en tales condiciones. [...] Las posibilidades de comunicación se habrán ampliado, pese a que los pasajeros menos cultivados no puedan desentrañar todavía el código con suficiente claridad y los más sofisticados (aquellos que creen que dentro del paréntesis se debería operar como fuera de él) pensarán que los signos son demasiado burdos, elementales y poco refinados. Pese a ello, buen número de pasajeros recibirá el mensaje y, teniendo en cuenta sus obligadas limitaciones a todos los niveles, sabrán leer su texto visible y su subtexto implícito, no olvidando que está emitido dentro del paréntesis y dirigido fundamentalmente a quienes en él están encerrados, sin que ello implique que pueda tener un interés histórico, documental o estético para los de fuera. Los cosmopolitas — extraño lujo el cosmopolitismo para los viajeros de la nave- despreciarán el mensaje, porque ellos conocen los códigos más libres del mundo exterior [...]. Pero quienes tienen clara conciencia de lo que implica vivir en la nave lo recibirán con alborozo, los más optimis- 
tas de ellos como un síntoma premonitorio de que el paréntesis está a punto de cerrarse, sabiendo que fuera de él su comentario también sería distinto. ${ }^{3}$

Sin embargo, el posibilismo es cuestionado desde la crítica cinematográfica ya a finales de los años sesenta. Respecto al posibilismo institucional, en la revista Nuestro Cine Vicente Molina Foix publica «Cineastas independientes, una tendencia del cine español»4 (1968), donde rechaza del cine protegido - o tolerado - por las instituciones cinematográficas franquistas. El crítico considera que la esperanza para lograr una auténtica ruptura reside en el cine alternativo, sobre todo por el hecho de moverse al margen de las estructuras industriales e institucionales. Este cine, que nace del amateurismo y muestra gran diversidad, comparte la lucha «contra las limitaciones expresivas y la exigencia de una labor independiente que alcance a un nuevo público y a un diferente concepto de espectáculo». Ahora bien, según el crítico, debe profundizar en «la voluntad de despego ideológico [...] de la industria y de las limitaciones que esta comporta, el deseo de una labor artística absolutamente desligada de los mecanismos represivos establecidos a diversos niveles, la aspiración a formular un nuevo lenguaje expresado con total libertad y de manifestar una ideología sin el habitual escamoteo». Tras la muerte de Franco le llega el turno al posibilismo discursivo, y en concreto al cine de Elías Querejeta y Carlos Saura. En el dosier dedicado al director aragonés publicado en Dirigido por (número 32), por ejemplo, Rafael Miret Jorba todavía aporta algunas de las claves de su obra y coloca El jardín de las delicias en un puesto destacado de lo que denominaba los «episodios nacionales saurianos», capaces de componer la historia espectral de España con la fusión de realismo y simbolismo, «un hiper-realismo total, que incluya lo que se ve y no se ve».5 Algunos números más tarde de la misma publicación (número 39), sin embargo, Juan Carlos Rentero considera a Saura, en su crítica a Cría cuervos (1976), la «oposición permitida» al Régimen franquista. Las circunstan-

3 Diario de Barcelona, 15 may. 1974. Sobre los problemas con la censura que padeció la película, véase Diego Galán, Venturas y desventuras de «La prima Angélica» (Valencia: Fernando Torres Editor, 1974).

4 Nuestro cine 77-78 (1968): 68-76.

5 «Carlos Saura», Dirigido por 32 (1976): 2-10.

FRANQUISME \& TRANSICIÓ 4 (2016) ISSN 2014-511X PUNCTUM, UNIVERSITAT OBERTA DE CATALUNYA \& FUNDACIÓ CARLES PII SUNYER 
cias han cambiado y pueden realizarse películas que aborden determinados temas de manera literal. Pero Saura, según el crítico, ha convertido la lectura entre líneas en una clave de su estilo, aunque ello le conduzca a un «cine restringido y elitista, intelectualizado y no revolucionario, supuestamente político pero ambiguo». En Cría cuervos «el espectador siempre se encuentra desbordado por la clave simbólico-subterránea». ${ }^{6}$

\section{El pasado en proceso de "generización"}

En la obra de Carlos Saura la presencia del pasado, en concreto de la Guerra Civil y de la posguerra, es determinante. Ahora bien, poco después de las tres películas mencionadas aparecen títulos como Pim, pam, pum... ifuego! (Pedro Olea, 1975), Retrato de familia (Antonio Giménez-Rico, 1976), Las largas vacaciones del 36 (Jaime Camino, 1976) o Los días del pasado (Mario Camus, 1977), que abordan directamente ambos periodos, ya sin recurrir a estrategias posibilistas, desde planteamientos opuestos a los establecidos con anterioridad por las instituciones cinematográficas de la dictadura para su tratamiento. Es cierto que en estas películas surgen nuevos temas y protagonistas, pero también lo es que evidencian los nuevos límites de lo visible y lo decible que el periodo transicional establece, aunque ahora sean más una asunción que una imposición de la censura. Ello implica no llegar demasiado lejos en el tratamiento del pasado, o hacerlo de manera que se contribuya a apuntalar el consenso ante la frágil democracia antes que incidir sobre heridas apenas cerradas. Además, estos títulos - con el antecedente de El espíritu de la colmena (Víctor Erice, 1973) - sientan las bases de la aparición y la consolidación de un nuevo género cinematográfico que ha pervivido hasta la actualidad; es decir, su articulación en el plano de la puesta en forma y la manera en que son abordados sus contenidos influye en la gran mayoría de las películas que con posterioridad han ambientado sus historias en la Guerra Civil o en la posguerra hasta el punto de generar en su audiencia una serie de expectativas, sustentadas en la redundancia, que deben ser satisfechas en su visionado. Este hecho no tiene precedente en el cine sobre el conflicto 
y sus consecuencias producido bajo el franquismo, cuando las películas podían recurrir a estrategias de diferentes géneros sin que por ello hubieran llegado a configurar uno propio.?

Este cine viene condicionado por el hecho de situarse en lo que Aróstegui denomina «memoria de la reconciliación» - mayoritaria hasta mediados de los años noventa-, en contraposición a la «memoria de la restitución o la reparación» — desde los años noventa hasta la actualidad-, ambas atadas a la relación que las distintas generaciones guardan con el conflicto. ${ }^{8}$ No obstante, su concreción en el cine presenta ciertas particularidades, que matizan el famoso «todos fuimos culpables» de la guerra. Según Enrique Monterde, estas películas encierran «una visión pequeño-burguesa que consolida la idea de una España mayoritariamente entregada a la vesania de los extremistas, tal como si esa clase media no se hubiera alineado bien con los partidos del republicanismo moderado (perdedores) o del derechismo cedista, claramente conspirativo y muchas veces para-fascista (mayoritariamente vencedores)».9 Es un cine, además, donde predomina el reconocimiento sobre el conocimiento, la memoria sobre la historia, donde no hay películas orientadas «hacia la propuesta de nuevos sentidos históricos [...], capaces de permitir comprender de "otra" manera la Historia (o incluso eventualmente "otra" historia)». ${ }^{10}$ La concentración de las historias en vivencias personales y familiares pequeño burguesas, aunque de ellas puedan sustraerse conclusiones más generales por la vía de los recursos retóricos - herencia del posibilismo discursivo-, el centrismo o el limitado reformismo, impide la creación «de una vía autónoma y metodológicamente bien planteada en la aproximación fílmica a la historia». ${ }^{11}$

7 Véanse Román Gubern, 1936-1939. La Guerra de España en la pantalla (Madrid: Filmoteca Española, 1986); Vicente SÁNCHEZ-BıosCA, Cine y Guerra Civil española. Del mito a la memoria (Madrid: Alianza, 2006), o Jorge Nieto FerRANDo, La memoria cinematográfica de la guerra civil española (Valencia: Publicacions de la Universitat de València, 2008).

8 «Traumas colectivos y memorias generacionales: el caso de la guerra civil», en Julio ArósteGui y François Godicheau, ed., Guerra Civil. Mito y memoria (Madrid: Marcial Pons, 2006), 57-92.

9 Enrique MONTERDE, «El cine histórico durante la transición política», en José Antonio HuRTADO y Francisco PICó, ed., Escritos sobre el cine español (1973-1987) (Valencia: Filmoteca de la Generalitat Valenciana, 1989), 59.

10 MONTERDE, «El cine histórico durante la transición política», 47.

11 Ibídem. 
Por otra parte, las películas mencionadas sientan las bases de lo que ha llegado a constituirse en un género cinematográfico, y ello ha hecho que el referente histórico quede cada vez más diluido en favor del referente genérico: es decir, que las películas que han abordado con posterioridad el conflicto ya no tienen tanto que ver con la guerra o la posguerra $-\mathrm{O}$ con otros discursos sobre la guerra y la posguerra- sino con sus compañeras de género.

En primer lugar, con ellas aparecen ya las dos grandes corrientes del género: las películas cuyas historias están ambientadas en la retaguardia - Retrato de familia y Las largas vacaciones del 36- y aquellas que las ambientan en la posguerra -Pim, pam, pum... ifuego! o Los días del pasado. Las primeras se caracterizan por la utilización de un patrón argumental propio del cine de terror y de catástrofes: lo que Jordi Balló y Xavier Pérez denominan «intruso destructor». ${ }^{12}$ El antagonista en estas películas es la propia "situación" generada por la guerra - esta es equiparable a una catástrofe natural-, que irrumpe en la vida de personajes inscritos en entornos familiares definidos por la indiferencia ante el conflicto o, en algunos casos, con una vinculación ideológica muy laxa con los defensores de la república, pero que acaban por padecer con toda su crudeza la guerra. Este intruso destructor suele hacerse presente poco a poco. Así, en Las largas vacaciones del 36 determinadas escenas gradúan dramáticamente entre elipsis su irrupción y muestran sus consecuencias: las crecientes carencias materiales de los protagonistas y la progresiva degradación de las relaciones familiares. Obsérvese que la indefinición del principal antagonista, el hecho de ser una situación antes que una «persona» que represente a un grupo social, contribuye a diluir las responsabilidades de la guerra.

$\mathrm{Si}$ en las películas ambientadas en la retaguardia el conflicto es «de situación» - los personajes han de enfrentarse a la situación generada por la guerra-, en aquellas cuya historia discurre en la posguerra el conflicto es social; es decir, unos personajes individuales o un grupo se enfrentan a otro grupo más poderoso: los primeros aparecen circunscritos al ámbito de los perdedores, mientras que los segundos siempre pertenecen

12 Jordi BALló y Xavier PÉrez, La semilla inmortal. Los argumentos universales en el cine (Barcelona: Anagrama, 1997), 73-88. 
a los vencedores. No obstante, de nuevo debido a las restricciones en los límites de lo decible y lo visible en la Transición, la España franquista como antagonista todavía no está definida con claridad. En Pim, pam, pum... ifuego!, el conflicto social queda rápidamente encarnado en un «conflicto de relación» — es decir, un conflicto entre «personas»— entre Paca (Concha Velasco) y Julio (Fernando Fernán Gómez), el estraperlista que la acosa. Es cierto que Julio es fruto de la sociedad injusta nacida de la guerra, pero no es exclusivo de esta; de hecho, en las películas ambientadas en la retaguardia republicana aparecen personajes sin escrúpulos del mismo cariz, que prosperan en ambos bandos. Esto, sin embargo, ha cambiado en títulos más recientes que pueden circunscribirse a la «memoria de la restitución», como Silencio roto (Montxo Armendáriz, 2002), Las trece rosas (Emilio Martínez Lázaro, 2007) o La voz dormida (Benito Zambrano, 2011), donde los antagonistas son representantes directos de las fuerzas represivas del Estado franquista, y los conflictos de relación quedan para las historias secundarias.

En segundo lugar, en las películas mencionadas ya se aprecian ciertas constantes recurrentes en títulos posteriores en lo referente a los personajes: los niños obligados a madurar; los emboscados, escondidos y huidos; personajes masculinos derrotados, impotentes en su lucha contra la dictadura o que han renunciado ya a ella y buscan la mera supervivencia, y sobre todo las mujeres que sufren en silencio la opresión de los vencedores o ayudan a maquis y otros perseguidos a pesar de las imposiciones de los vencedores. En las acciones de estos personajes en las películas ambientadas en la posguerra se aprecia la influencia de otro patrón argumental con larga tradición en el cine y la literatura: el de Antígona, la mujer que ayuda al vencido, a pesar de todas las prohibiciones públicas, con consecuencias trágicas. ${ }^{13}$

Finalmente, otra característica de género que ya aparece en estas películas es el carácter sinecdóquico de sus personajes y los acontecimientos que narran; es decir, estos diluyen su singularidad al mostrarse como concreciones de situaciones generales o grupos más amplios con entidad extrafílmica. En ocasiones esto aparece explicitado por la crítica,

13 Ibídem, 104-114. 
las declaraciones de los directores - así sucede con los comentarios de Camus sobre Los días del pasado- ${ }^{14} \mathrm{O}$ en las propias películas: «Los hechos de esta película ocurren en un pueblecito de Cataluña, donde, como en otros muchos, las familias burguesas de la ciudad pasaban sus vacaciones aquel verano de 1936», aparece en un rótulo al principio de Las largas vacaciones del 36 . Los recursos empleados en la puesta en escena contribuyen a diluir la singularidad de los personajes. Así sucede en las primeras escenas de Pim, pam, pum... ifuego! o de Los días del pasado, ${ }^{15}$ en ambos casos ambientadas en un vagón de tren de tercera, donde mediante la planificación se muestra cómo las historias de sus protagonistas podrían ser las de cualquiera de los pasajeros.

\section{Reflexividad y lucha en el plano de la expresión}

Como hemos visto, el fin del discurso posibilista no excluye el establecimiento de un nuevo horizonte de lo visible y lo decible. Esto afecta también al cine de no ficción. En este sentido es ejemplar La vieja memoria (Jaime Camino, 1978). La película rompe con buena parte de las restricciones anteriores en el tratamiento de un tema tan complicado como la Guerra Civil para componer una de las mejores aproximaciones al conflicto, asentada en la confrontación de distintas memorias, de distintos testimonios de diferentes dirigentes políticos y militares protagonistas de la República y la Guerra Civil. Su montaje y puesta en escena permiten establecer asociaciones de imágenes imposibles, sugerir mediante algunos raccords diálogos entre personas como Dolores Ibárruri, Federica Montseny, José María Gil-Robles, Enrique Líster, David Jato Miranda, Raimundo Fernández Cuesta, Josep Tarradellas o Frederic Escofet, entre otros, muy alejadas física e ideológicamente, cuyo único diálogo anteriormente había sido el de las armas. Jaime Camino profundiza con su película en la apertura de los límites de lo decible y lo visible — presentaba personajes proscritos durante cuarenta años-, pero su espectacu-

14 Mario Camus, «Los días del pasado», El País, 28 feb. 1978.

15 Véanse Santos Zunzunegui, Paisajes de la forma. Ejercicios de análisis de la imagen (Madrid: Cátedra, 1994), 42-70, y Jorge Nieto FERRANDO, «Introducción al cine de ficción sobre la guerra civil como género cinematográfico. Terror, historia y melodrama», Signa 25 (2016): 803-823. 
lar labor de montaje la mantiene en perfecta sintonía con el «consenso», con ese nuevo marco de lo posible asentado sobre la intención de dirimir las diferencias pacíficamente, negociando, dialogando.

No obstante, el cine de no ficción producido en los márgenes externos de los canales de producción, distribución y exhibición presenta posiciones mucho más críticas en su tratamiento del presente y del pasado. Es un cine, además, que, justamente por su independencia, ya a finales de los años sesenta deja atrás toda estrategia posibilista de negociación con la censura con el objetivo de contrainformar e incluso incitar desde la militancia a la acción política. Su importancia reside, en primer lugar, en el hecho de realizarse, dado que es común considerar que el documental implica un «pacto de veracidad» con el espectador sobre la base de la asunción de cierta correspondencia, de alguna manera susceptible de ser corroborada - la mayor parte de las veces a través de otros discursos sobre el mismo tema-, entre el contenido abordado por las películas y la realidad. Por este motivo, el documental, y en general los discursos audiovisuales de carácter informativo o referencial, fue atado en corto por las instituciones cinematográficas franquistas. El mero hecho de realizar documentales aprovechando los resquicios de dichas instituciones, o directamente fuera de ellas, a finales de los años sesenta y principios de los años setenta constituye un acto de oposición a la dictadura. En segundo lugar, es relevante por abordar temas como la pobreza y la miseria, la migración del campo a la ciudad y el crecimiento desordenado de los barrios periféricos en las grandes urbes, la situación de los presos políticos y de las minorías y los grupos sociales marginados, la lucha obrera y estudiantil por los derechos sociales, la libertad y la democracia, o la represión ejercida por el Estado y sus reminiscencias tras la muerte de Franco; temas de difícil tratamiento en esos momentos y en gran medida ausentes en el No-Do y en los informativos televisivos. En tercer lugar, y quizá lo más interesante, es importante porque no se reduce a mostrar aspectos de una realidad diferente a la expuesta por el No-Do - el qué-, sino que también se enfrenta a las estrategias narrativas y representativas empleadas para ello - el cómo.

Películas como Monegros (Antonio Artero, 1969), El largo viaje hacia la ira (Llorenç Soler, 1969), El cuarto poder (Helena Lumbreras, 1970), 
Noticiario RNA (Llorenç Soler, 1970), Sega Cega (José Gandía Casimiro, 1972), La ciudad es nuestra (Tino Calabuig y Miguel Ángel Cóndor, 1975), El campo para el hombre (Helena Lumbreras y Mariano Lisa, 1975), Hasta siempre en la libertad (Colectivo de Cine de Madrid, 1976), Informe general sobre algunas cuestiones de interés para una proyección pública (Pere Portabella, 1976) o, entre muchas otras, Numax presenta (Joaquim Jordà, 1977), se caracterizan por romper con las estrategias narrativas del documental expositivo, propias también del noticiario, y esto a través de la proliferación de narradores de muy diverso tipo, lo que contrasta con la uniformidad del narrador en over del No-Do, una relación mucho más compleja entre la banda sonora y la imagen, que ya no es redundante o ilustrativa respecto al relato en over, y la reflexión sobre el propio carácter del cine documental como relato sobre la realidad, apostando por romper con la supuesta transparencia en su aproximación a ella.

Estas tres características están interrelacionadas. El narrador en over ya no es la única instancia capacitada para concretar el sentido de las imágenes. Muchas películas muestran una mayor confianza en dichas imágenes, además de llenarse de personajes que ejercen de narradores y, por tanto, sus testimonios tampoco se reducen a ser mera ilustración de la voz en over, como suele suceder en el noticiario o en los telenoticias. Estos personajes, además, pueden en ocasiones reconstruir acciones, diálogos o acontecimientos, incluso circunscribirse claramente al ámbito de la ficción, lo que contribuye a la disolución de cualquier voluntad de transparencia o de vínculo estrecho entre la representación documental y la realidad. De igual manera sucede con la relación entre la banda sonora - ya sean ruidos, músicas o locuciones - y la imagen, donde la redundancia o la ejemplaridad es superada por la complementariedad y la contradicción. Ello conduce en muchas ocasiones al distanciamiento irónico, lo que de nuevo enturbia la relación entre representación y realidad. El distanciamiento también se genera en algunas películas a partir de la exhibición de las marcas que denotan la condición de construcción y artificio del documental. Entre los recursos más frecuentes encontramos la presencia de los dispositivos de registro y de reproducción de la imagen o la continua ruptura con la ilusión, cuando algunos de los narradores reflexionan directamente sobre la relación entre el cine y la realidad. 
Este cine de no ficción alternativo es mucho más radical en sus planteamientos, que se concretan en el plano del contenido y del discurso: rompe con el posibilismo, apuesta por abordar sus temas sin trabas, aunque ello le excluya de los canales pautados por las instituciones cinematográficas del franquismo y la Transición. No obstante, emplea también la ironía, la parodia, el símil, la sinécdoque, la alusión, etc., recursos propios del cine posibilista, aunque su objetivo ahora es la persuasión, más que la elusión, en estrecha relación con la función agitadora atribuida a algunas de sus películas.

\section{Conclusión}

La oposición antifranquista en el cine recurre al discurso posibilista para eludir la acción de la censura, pero al mismo tiempo es tolerada por las instituciones cinematográficas del Régimen. El origen de este discurso posibilista puede situarse en Muerte de un ciclista, dirigida por Juan Antonio Bardem en 1955, cuya configuración alegórica permitió exponer una interpretación de la guerra y sus consecuencias en términos de lucha de clases, algo sin duda proscrito, lo que pasó desapercibido para la censura, que solo puso reparos a la relación adúltera de sus dos protagonistas. ${ }^{16}$ Pero es en el cine de Carlos Saura y del productor Elías Querejeta donde alcanza su mayor grado de desarrollo. No obstante, el posibilismo discursivo e institucional es cuestionado ya en el tardofranquismo, sobre todo con la aparición de un cine opositor de carácter alternativo, y, tras la muerte de Franco, con la exigencia de mayor literalidad en el tratamiento de los temas que anteriormente habían estado sujetos a las restricciones franquistas.

Uno de esos temas es la Guerra Civil. Las películas que abordan este episodio clave del pasado se enfrentan con claridad al tratamiento recibido por él en el cine no disidente durante el franquismo. Sin embargo, están sometidas a la doctrina del consenso y de la reconciliación, lo

16 Véase Juan Francisco CERón, «Además de las palabras. Las películas proyectadas durante las Conversaciones de Salamanca», en Jorge Nieto FER RANDo y Juan Miguel Company RAmón, coord., Por un cine de lo real. Cincuenta años después de las «Conversaciones de Salamanca» (Valencia: Ediciones de la Filmoteca, 2006), 99-108. 
que imprime a su tratamiento un carácter muy particular, con una profunda repercusión en el cine que, con posterioridad, aborda el conflicto, al sentar las bases de un «nuevo» género cinematográfico. Son películas que toman elementos del cine de terror y de catástrofes - el patrón argumental del intruso destructor-, del cine histórico - aunque su verosimilitud cada vez requiere menos de otros discursos sobre el pasado y más de las convenciones genéricas-, de la tragedia - el patrón argumental de Antígona - y del melodrama familiar - los personajes femeninos e infantiles - para componer unos contenidos recurrentes y una estructura formal repetitiva y previsible, lo que es propio de un género. Es un cine, además, que apela más a la memoria que a la historia, circunscrito a la reconciliación antes que a la restitución.

Con todo, las propuestas más radicales provienen del cine de no ficción realizado fuera de las instituciones cinematográficas del franquismo y de la Transición. Este cine aborda temas proscritos y lo hace enfrentándose a los discursos del noticiario No-Do y de los telenoticias, además de incitar a la reflexión sobre la relación entre la representación documental y la realidad. No obstante, sus dardos ya no se dirigen al franquismo, sino que buscan el capitalismo, ya que consideran la dictadura como un epifenómeno de las relaciones sociales de producción capitalistas. 